\title{
Chile: Selected Issues Paper
}

This Selected Issues paper on Chile was prepared by a staff team of the International Monetary Fund as background documentation for the periodic consultation with the member country. It is based on the information available at the time it was completed on June 19,2008. The views expressed in this document are those of the staff team and do not necessarily reflect the views of the government of Chile or the Executive Board of the IMF.

The policy of publication of staff reports and other documents by the IMF allows for the deletion of market-sensitive information.

\author{
Copies of this report are available to the public from \\ International Monetary Fund $\bullet$ Publication Services \\ $70019^{\text {th }}$ Street, N.W. • Washington, D.C. 20431 \\ Telephone: (202) 623-7430 • Telefax: (202) 623-7201 \\ E-mail: publications@imf.org Internet: http://www.imf.org
}

Price: $\$ 18.00$ a copy

\section{International Monetary Fund Washington, D.C.}





\section{INTERNATIONAL MONETARY FUND}

\section{CHILE}

\section{Selected Issues}

Prepared by N. Batini, J.P. Walsh, E. Tereanu (all WHD), Z. Arvai, M. Papaioannou, M. Singh (all MCM), and A. Matsumoto (RES)

Approved by the Western Hemisphere Department

June 19, 2008

Contents

Executive Summary

\section{Technical Notes}

I. Supply Shocks, Inflation, and Expectations .....................................................

II. What is the Optimal Level of International Reserves for Chile?............................6

\section{Summaries of Analytical Papers}

III. An Evaluation of the Welfare Implications of Chile's Macroeconomic Framework....9

IV. How do Changes in Global Liquidity Affect Chile? ............................................... 12

\section{Background Work}

V. Sovereign Wealth Funds: An International Perspective ........................................15

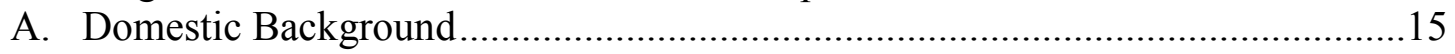

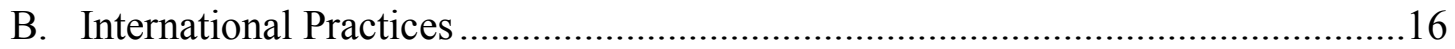

C. Rules and Institutionality: How does Chile Compare? ...................................... 18

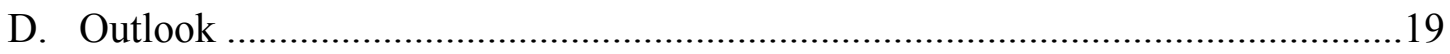

VI. Deepening Chile's Capital Markets Through Global Integration .............................21 


\section{EXECUTIVE SUMMARY}

1. This Selected Issues paper provides further background on analytical work discussed in the Staff Report. The paper also includes an overview of technical assistance on sovereign asset allocation and financial sector reform.

\section{Technical Notes}

2. The first chapter examines the acceleration of inflation over the past year, identifying domestic shocks to food and energy prices as main drivers. The note indicates that domestic shocks may also have increased the pass-through of changes in global commodity prices to headline inflation in Chile. Increases in the central bank's policy rate have helped anchor longrun inflation expectations and supported the real interest rate.

3. Chapter II uses the Jeanne-Rancière model to calculate Chile's optimal ratio of international reserves to GDP. Results show that the central bank's recent decision to partially reverse a reduction in reserves initiated in 2003 looks prudent in the light of plausible output costs in the case of a sudden stop.

\section{Summaries of Analytical Papers}

4. Chapter III analyzes the stabilization properties of Chile's macroeconomic framework and compares it to alternative policy rules. It concludes that Chile's framework based on an explicit inflation target, a floating exchange rate and a structural fiscal surplus rule is superior to other arrangements, especially a managed float or fiscal rules targeting a balanced budget or stable debt-to-GDP-ratio.

5. The fourth chapter explores the impact of changes in global liquidity on Latin American countries, with a special focus on Chile. It finds that the impact of changes in global liquidity varies across countries, with Chile appearing most resilient to shocks largely thanks to its credible inflation targeting regime.

\section{Background Work}

6. Chapter V compares the role of Chile's SWFs to other countries. In the context of government plans to revise the funds' strategic asset allocation framework, the analysis confirms that portions of the funds could be invested into assets with longer duration without jeopardizing the funds' pension funding and economic stabilization objectives.

7. Chapter VI focuses on further integrating Chile's well-developed financial markets into the global economy. It concludes that removing obstacles for foreign investors and strengthening the financial sector infrastructure, as well as improving the framework for public debt management, would go a long way in achieving this objective. 


\section{SUPPLY SHOCKS, INFLATION, AND EXPECTATIONS ${ }^{1}$}

Inflation began to accelerate in the second half of 2007. While partly caused by global developments, inflation rose faster than in many other countries due to simultaneous shocks at home. However, long-term inflation expectations remain anchored close to the 3-percent target, and the recent tightening of monetary policy has bolstered real interest rates.

1. Inflation began to accelerate in mid2007 after a long period of price stability.

Chile's inflation rate averaged $3 \frac{1}{2}$ percent a year between 1997 and 2007, and has remained well within single digits since the introduction of inflation targeting in 1990. After rising to $73 / 4$ percent at end-2007, annual inflation reached close to 9 percent in May 2008-5 percentage points above the Central Bank's upper tolerance level.

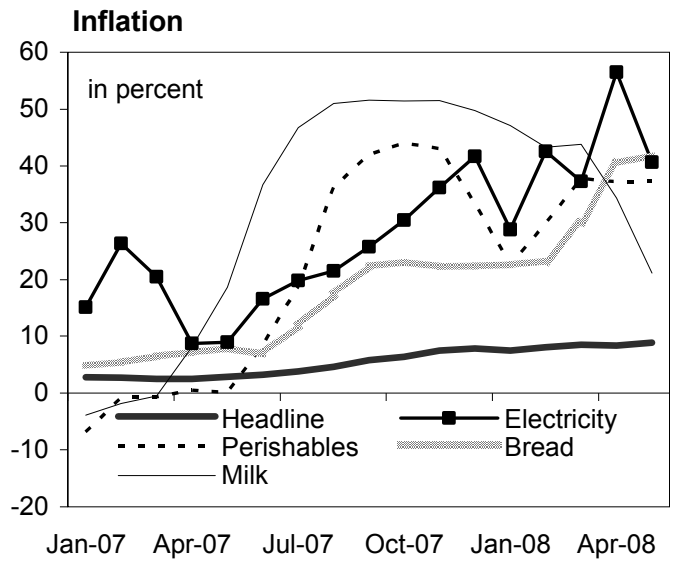

2. The increase in inflation was driven primarily by food and energy components. Annual price increases in key food staples reached up to 50 percent, and the cost of electricity has been almost 60 percent higher than in the first half of 2007. Given the relatively high weight of food and energy in the consumer price index, these trends dominated price developments of other goods, which have largely conformed to the central bank's inflation target.

3. In contrast to many other countries, jumps in food and energy prices in Chile also reflect large domestic supply shocks. The contribution of food and fuel components to inflation in Chile is among the highest across emerging market economies, notwithstanding the fact that other countries have a similar or even larger weight on these components (see table below). Since countries are being hit by global shocks in a broadly similar way, the difference in the contribution of price components to inflation largely reflect domestic supply conditions and price subsidies. Chile has none of the latter-instead, natural gas shortages

\begin{tabular}{|c|c|c|c|c|c|c|c|}
\hline \multicolumn{8}{|c|}{ Food and Fuel Inflation--Weights and Contributions } \\
\hline \multirow[t]{2}{*}{ Countries } & Inflation & & Food & & & Fuel & \\
\hline & 03-08/03- 07 & Weight (\%) & Composition & Contr. (\%) & Weight (\%) & Composition & Contr. (\%) \\
\hline BRA & 4.7 & 21.7 & Food and beverages & 2.4 & 5.0 & Fuels & 0.0 \\
\hline $\mathrm{CHL}$ & 8.5 & 27.2 & Food & 4.4 & 4.0 & Fuels & 0.8 \\
\hline $\mathrm{COL}$ & 5.9 & 29.5 & Food & 2.7 & 1.1 & Fuels & 0.2 \\
\hline MEX & 4.2 & 22.7 & Food & 1.5 & 3.8 & Gasoline and lubricating oils & 0.2 \\
\hline PER & 5.5 & 47.5 & Food and beverages & 4.4 & 2.5 & Fuels & 0.2 \\
\hline SA & 7.0 & 27.0 & Food & 3.6 & 10.5 & Housing-fuel, power, transport costs & 2.7 \\
\hline CZR & 7.1 & 16.3 & Food + non-alcoholic beverages & 1.8 & 11.4 & Transportation & 0.7 \\
\hline ISR & 3.7 & 17.1 & Food (including fruits and vegs) & 1.9 & 17.1 & Transportation & 0.6 \\
\hline THA & 5.3 & 36.1 & Food + non-alcoholic beverages & 2.9 & 9.1 & Energy & 2.0 \\
\hline
\end{tabular}

\footnotetext{
${ }^{1}$ Prepared by Nicoletta Batini.
} 
have added to local inflation, and so has a drought that increased the costs of local agricultural products and hampered the production of hydro-electricity.

\section{Domestic shocks may also have} increased the pass-through of changes in global commodity prices to headline inflation in Chile. Historically, the passthrough of import prices to the CPI has been falling, and inflation has not been very sensitive to spikes in global food and energy prices. For example, dynamic correlations between changes in the CPI and the Chicago Research Bureau's (CRB) grains and seeds, livestock, foodstuff, and energy sub-indices - computed over the period 2000-2008 - are low and not statistically different from zero, unlike in a number of other inflation-targeting emerging markets. In recent months, however, the correlation may have increased, given more precarious domestic supply conditions and the need to import significant amounts of diesel to replace other electricity-generating services.

5. Economic agents have reacted to the price shock with higher short-term inflation expectations and a pick-up in wages.

Although some domestic prices remain indexed, long-run inflation expectations are a key mechanism for the transmission of recent price shocks to the economy. These expectations have so far increased only
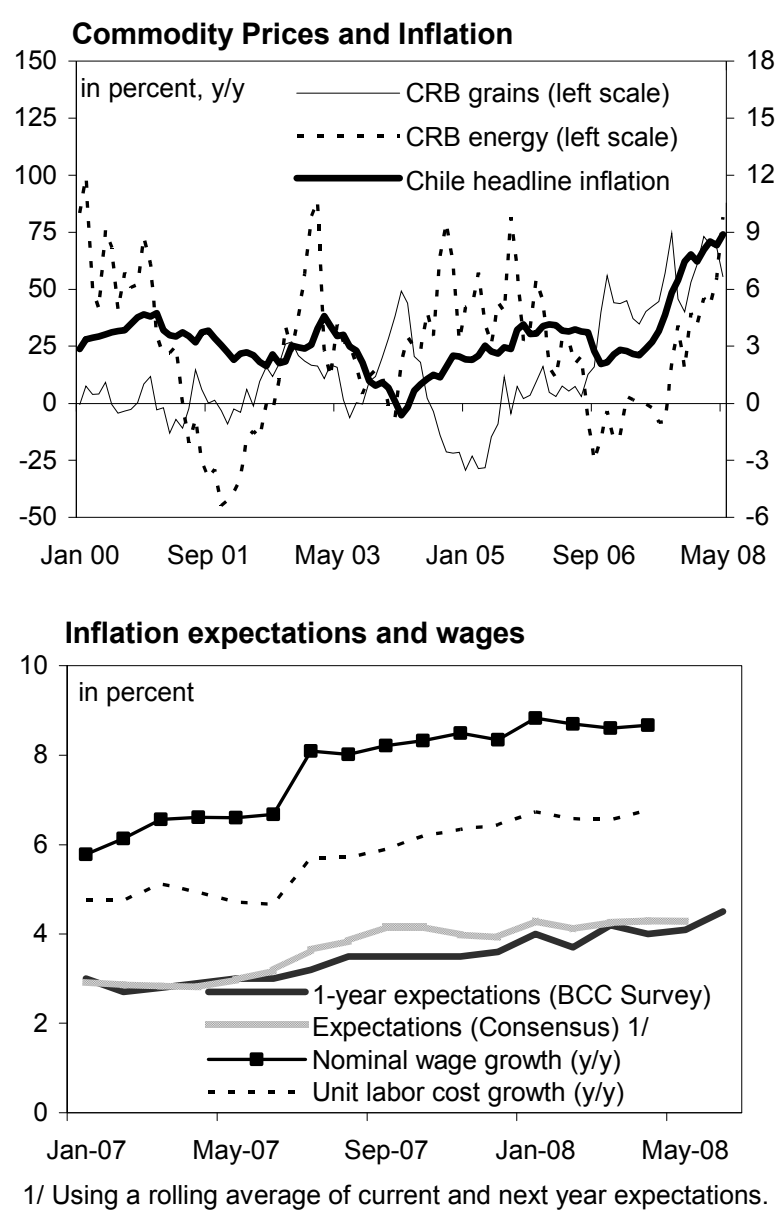

Alternative short-term inflation expectations

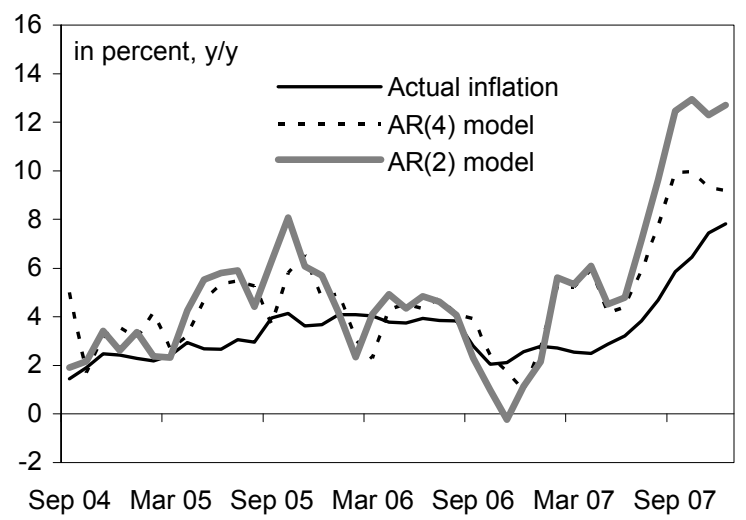
moderately, both compared to other emerging economies and the central bank's inflation target. However, short-run expectations (as generated, for example, by simple recursive models) have ratcheted up as nominal wages have largely caught up with headline inflation. ${ }^{2}$

\footnotetext{
${ }^{2}$ Staff has estimated simple AR(2) and AR(4) short-run inflation expectations models on monthly Chilean CPI data over the period January 2004-January 2007. Out-of-sample dynamic forecasts using both models suggest that one-month-ahead expectations by myopic agents track closely actual inflation, and rise well above long-run
} 
Further increases in short- and long-term inflation expectations could add to wage pressures going forward.

6. Similarly to many other emerging markets, real interest rates in Chilemeasured using actual or short-run expectations of inflation-have declined over the past year. While the decline looks larger than in many other emerging market economies, the central bank's 175 basis points increase in interest rates since last

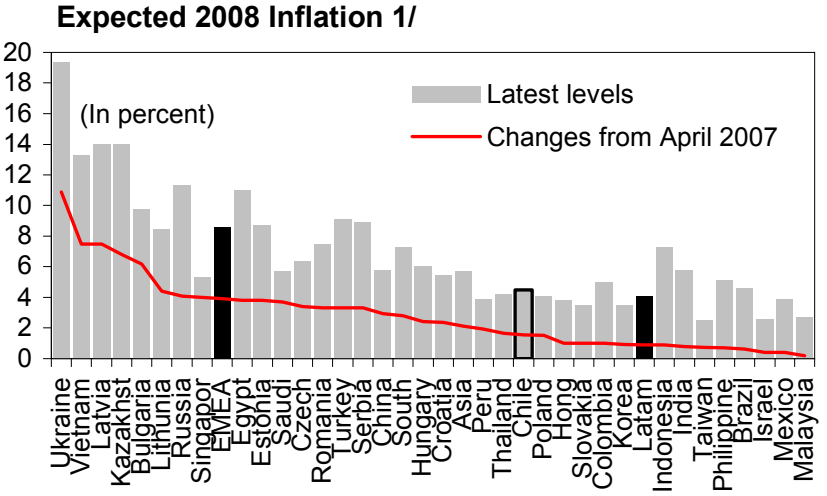

Sources: Consensus Forecasts and Fund staff estimates. 1/ Using 2008 inflation expected in April 2007 and April 2008. August, together with relatively stable long-run inflation expectations, implies that real interest rates based on price expectations with a horizon of one year or more have been constant or even rising over the past year.
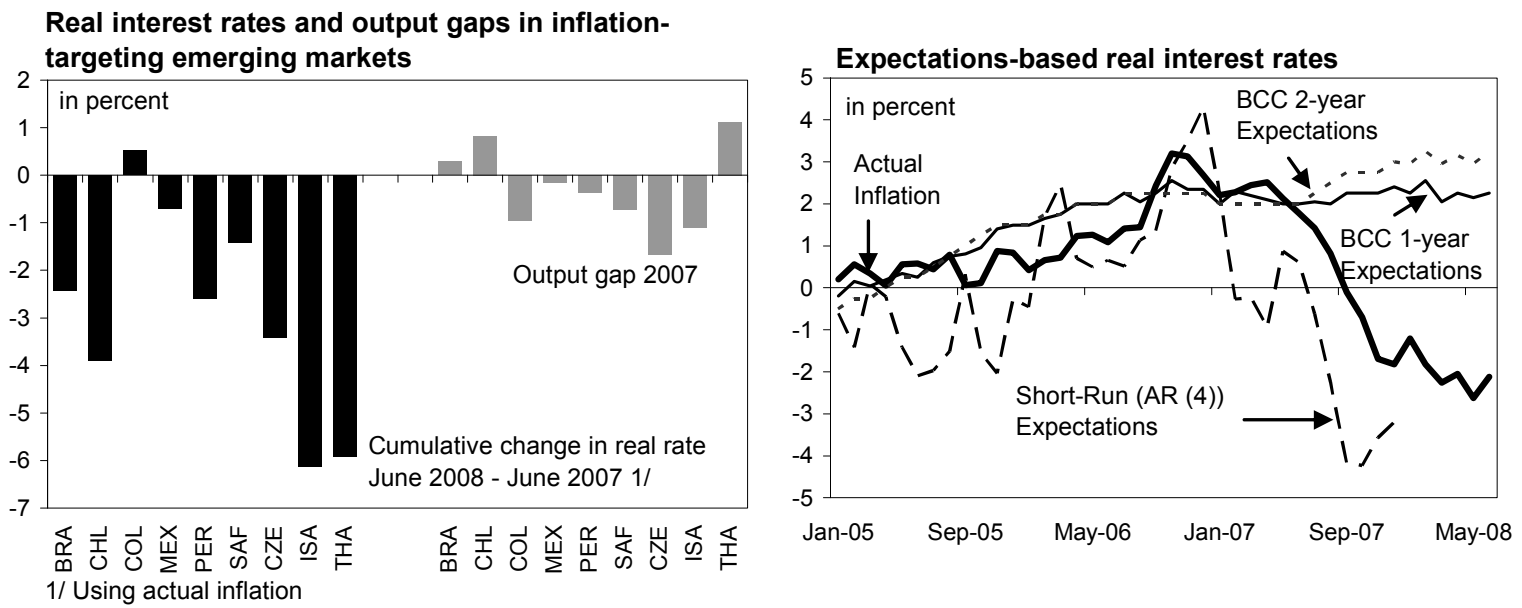

measures of expectations. Short-run expectations under the more inertial AR(4) model rise less, but are still well above the Central Bank target and long-run inflation expectations. 


\section{What Is The Optimal Level Of International Reserves For Chile? ${ }^{1}$}

Chile's ratio of international reserves to GDP has exceeded the average of Latin American countries for most of the past ten years. However, the central bank's recent decision to partially reverse a reduction in reserves that started in 2003 is prudent in the light of potential output costs in case of a sudden stop.

1. In April 2008, the Central Bank of Chile decided to acquire US\$8 billion (5 percent of GDP) in foreign exchange reserves, bringing the stock of reserves to around 15 percent of GDP by year's end. While Chile's policy framework has been successful in reducing the impact of external shocks, the central bank decided to boost external liquidity to be prepared for a possible further deterioration in the global financial environment. The bank also noted that the intervention was consistent with the peso being above its long-term equilibrium.

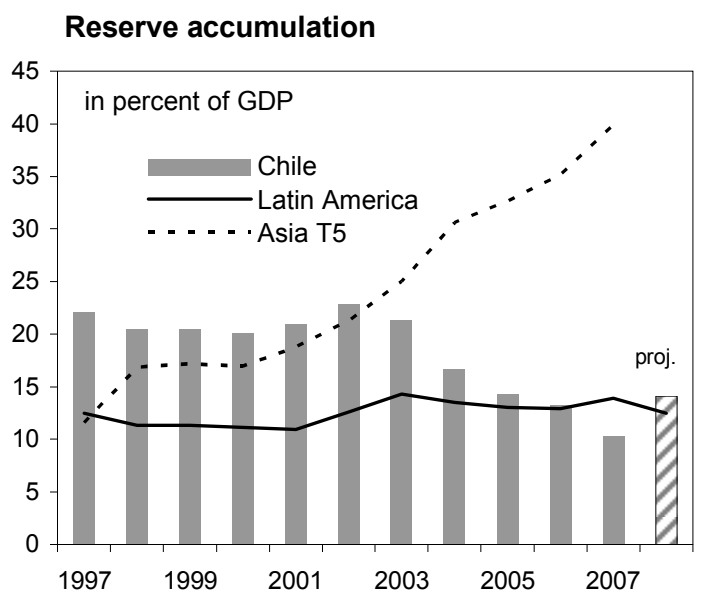

\section{This decision partially reverses the decline of Chile's gross international reserves} since 2003. At the time, Chile's reserve-to-GDP ratio was around 20 percent of GDP, comparable to several East Asian countries that have since accumulated much larger reserves, but above that of most other Latin American countries. The authorities then considered that it was costly to hold large amounts of reserves, that there was a reduced need for reserves under a floating exchange rate system, and that assets accumulated in Chile's sovereign wealth funds could complement international reserves in case of a sudden stop (Garcia, 2007; Valdes, 2006). However, Chile's economy and external trade have continued to grow strongly, and reserves coverage declined below the levels of other countries, including in Latin America.

\section{To assess the bank's recent decision, this chapter applies the methodology by} Jeanne and Rancière (2006) to calculate an optimal level of reserves for Chile. The model portrays a small open economy, where reserves allow the country to smooth domestic absorption in response to sudden stops. Reserves are assumed to yield a lower return than the interest rate on the country's long-term debt. The formula for the optimal level of the reserveoutput ratio, $\rho$, is: $\rho \approx \lambda+\gamma-\left(1-p^{-1 / \sigma}\right)$, where $\lambda$ is the level of private external debt as a share of output in the pre-sudden-stop period; $p$ is the marginal rate of substitution between

\footnotetext{
${ }^{1}$ Prepared by Eugen Tereanu.
} 
consumption in the sudden-stop state and consumption in the non-sudden-stop state; $\gamma$ is the output cost of the sudden stop; and $\sigma$ is the coefficient of relative risk aversion.

\section{4. $\quad$ The model is calibrated using} assumptions in a recent paper by the Central Bank of Chile. Calibrations of the output costs of a sudden stop follow Garcia and Soto (2006). The cost of a "benign" event would involve a 5 percent drop in GDP relative to trend, while the more severe stops would trigger contractions in

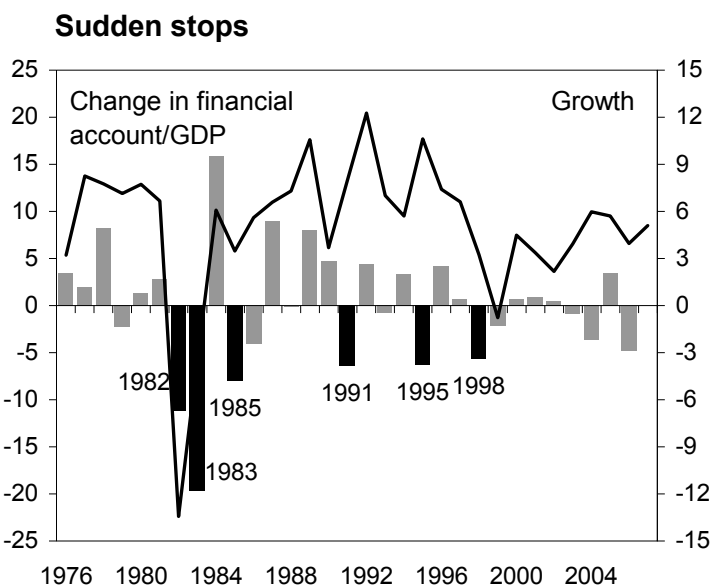
GDP of 10 and 15 percent, respectively. The annual probability of a sudden stop is set to 10 percent, consistent with the Jeanne-Rancière benchmark.

5. The results suggest that Chile's targeted level of reserves is optimal for plausible parameterizations of the model. While generally above the level found to be optimal for a typical emerging market economy by Jeanne and Ranciere (about 10 percent of GDP), the result is consistent with Chile being closely integrated into the global economy, possibly requiring a larger cushion to guard against shocks. It would only be optimal to hold larger amounts of reserves if the output costs of a sudden stop were assumed to be exceptionally severe.

\section{The model-based level of optimal reserves is not particularly sensitive to the} probability of a sudden stop. Even when a sudden stop is very likely, the optimal level of reserves does not exceed 15 percent of GDP in case of moderate output losses. This result is also consistent with recent finding by Kim (2008), who used the global games framework by Morris and Shin (2006) to establish a unique relationship between the probability of a sudden stop and the level of reserves.
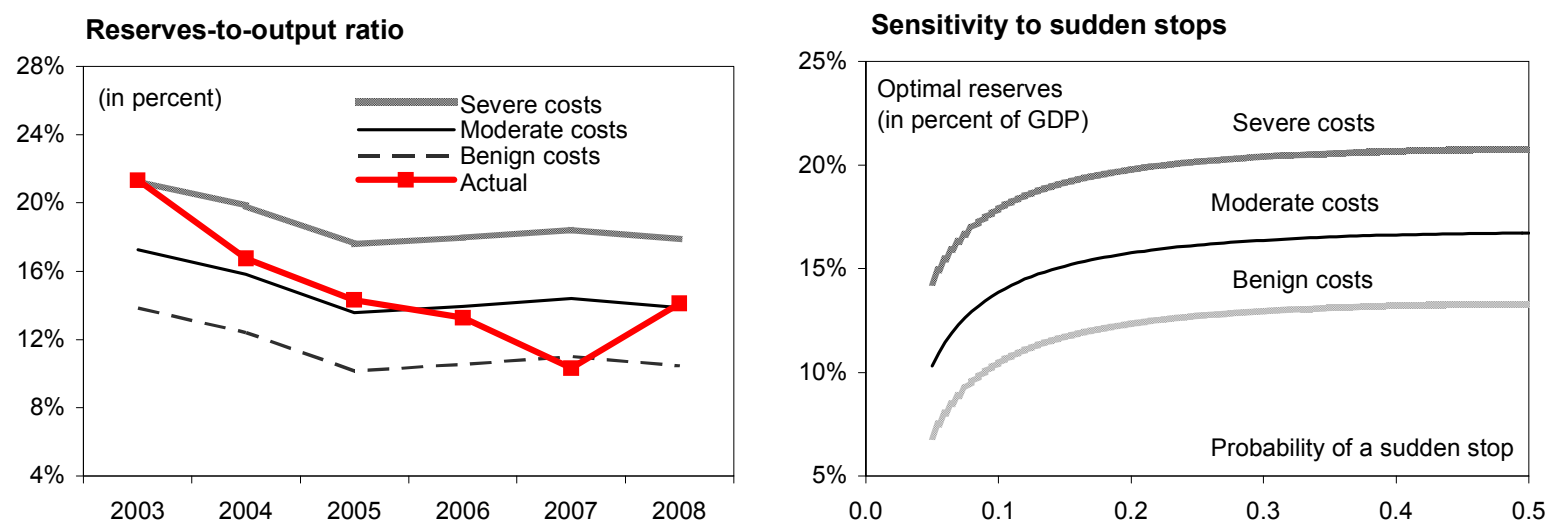


\section{References}

Garcia, P., 2007, "International Reserves Policy under Inflation Targeting-The Case of Chile," paper presented at FLAR's II International Conference: “International Reserves in Middle-and Low-Income Countries: Background of Recent Accumulation, Management, Monetary and Exchange Rate Policy, and Outlook."

_ It?” in: R. Caballero, C. Calderón and L. Céspedes (eds.), External Financial Vulnerability and Preventive Policies, Eight Annual Conference of the Central Bank of Chile, Santiago.

Jeanne, O., and R. Rancière, 2006, “The Optimal Level of International Reserves for Emerging Market Countries: Formulas and Applications," International Monetary Fund Working Paper 06/229.

Kim, J.I., 2008, “Sudden Stops and Optimal Self-Insurance”, International Monetary Fund Working Paper 08/144.

Morris, S., and H.S. Shin, 2006, “Catalytic Finance: When Does It Work?” Journal of International Economics, Vol. 70, Issue 1, pp. 161-177.

Valdes, R., 2006, "International Reserves Level in Chile and a Few Thoughts on Pooling," paper presented at the XXIV. Meeting of the Latin American Network of Central Banks and Finance Ministries, Inter American Development Bank. 


\section{An EVALUATION OF THE WeLFARE IMPLiCATIONS OF CHILE'S MACROECONOMIC FRAMEWORK ${ }^{1}$}

1. Thanks to a series of reforms begun in the early 1990s, Chile enjoys a forwardlooking and transparent macroeconomic framework centered on three pillars: an explicit target for inflation, a floating exchange rate and a fiscal rule that targets a structural surplus of $1 / 2$ percent of GDP aimed at eliminating the procyclical bias of fiscal policy.

2. Chile's rule-based approach has delivered important results. Over the past 15 years, inflation has fallen to low single digits, averaging 31/2 percent per year between 1997 and 2007; Chile is now a net external creditor; and both output and the real exchange rate have become more stable with respect to copper prices. With the creation of two SWFs in 2006, fiscal surpluses over and above the rule's target have generated a large stock of public assets, providing a buffer against shocks and helping deal with contingent liabilities. ${ }^{2}$

\section{This chapter analyzes the stabilization properties of Chile's macroeconomic} framework, and compares its implications for welfare relative to alternative policy rules. Monetary rules considered include an optimal model rule, simple Taylor-type rules mimicking an exchange rate targeting regime, a managed float, Chile's explicit CPI-inflation targeting rule, and a rule on PPI inflation. Since Chile's inflation target (3 percent) is in the low single digits, monetary rules are modified to impose a zero lower bound (ZLB) on nominal interest rates. ${ }^{3}$ Fiscal rules considered include an optimal model rule, a balanced budget rule, and three variants of the structural surplus rule. To mimic Chile's approach, the instrument of fiscal policy is taken to be taxes net of transfers. In all cases, coefficients in the rules are chosen to maximize social welfare by optimizing the utility of households.

4. The analytical framework is provided by a standard two-bloc emerging market-rest of the world DSGE model à la Medina and Soto (2007), calibrated on Chile's historical data. In the emerging market bloc, a portion of households has no access to credit, and firms are vulnerable to changes in the exchange rate because part of their borrowing is in dollars, as in the "open-economy financial accelerator" model of Gertler, Gilchrist and Natalucci (2001, GGN). Like Chile, the emerging market economy is rich in copper reserves and sells these abroad at a price in dollars that depends on foreign demand.

\footnotetext{
${ }^{1}$ This chapter provides a summary of a paper prepared by Nicoletta Batini (WHD), Paul Levine (University of Surrey) and Joseph Pearlman (London Metropolitan University).

${ }^{2}$ The Pension Reserve Fund (PRF) and the Fund for Economic and Social Stabilization (FESS).

${ }^{3}$ As in Woodford (2003), the ZLB constraint is implemented by modifying the single-period welfare loss to include a constraint on the variability of the nominal interest rate, set up such that the probability that the interest rate goes to zero or below zero is very low.
} 
5. Welfare is measured by approximating the utility of households following Woodford (2003). Woodford's "small distortions" assumption allows the quadratic approximation to the household's single period utility to be accurate as long as the zeroinflation steady state is close to the social optimum.

6. Model results support Chile's choice of policies:

- It is optimal to commit to flexible exchange rates and an inflation target. This policy is superior to partially or fully attempting to stabilizing the exchange rate. Responding to the exchange rate explicitly or implicitly makes it more expensive in terms of output variability to stabilize inflation. A model corollary is that stabilizing domestic inflation (e.g., measured by changes in the producer price index) enhances welfare outcomes somewhat, since stabilizing changes in the consumer price index implies a partial response to the exchange rate via imported consumer goods. ${ }^{4}$

- $\quad$ Financial frictions increase the costs of stabilizing the exchange rate, as shown in GGN and Batini et al. (2007), because the central bank cannot offset a drop in net worth by allowing the exchange rate to adjust. Emerging markets faced with financial frictions should thus "fear to fix" rather than "fear to float."

- $\quad$ Structural surplus fiscal rules are also optimal. A structural surplus fiscal rule that strictly pursues the fiscal target outperforms both balanced-budget rules and rules that try to achieve a specific structural surplus by responding to deviations of debt-to-GDP from a certain target. This rule minimizes the loss in consumption that households have to face in order to stabilize any given shock.

\section{The combination of Chile's three policy pillars has very desirable stabilization} properties. The structural surplus fiscal rule responds aggressively to cyclically-adjusted tax revenue and to the deviation of copper revenues from their long-term level, as in Medina and Soto (2007). This counter-cyclical fiscal feedback replaces the counter-cyclical monetary feedback on output growth, implying that lower nominal rates are needed to stabilize inflation, other things equal, when fiscal policy follows a rule like in Chile.

\footnotetext{
${ }^{4}$ This finding is inherent in the type of models employed by this chapter and does not suggest a different monetary policy objective, given that it is contingent on maximization of the utility of the representative agent as opposed to nonutility-based loss functions used elsewhere in the literature.
} 
Table 1: Monetary and Fiscal Assignments Considered in the Analysis

\section{Monetary Policy Assignment}

\begin{tabular}{|c|c|}
\hline Inflation Target (CPI) & $r_{n, t}=\rho r_{n, t-1}+\theta_{\pi} E_{t} \pi_{t}+\theta_{y} \Delta y_{t}$ \\
\hline Inflation Target (PPI) & $r_{n, t}=\rho r_{n, t-1}+\theta_{\pi} E_{t} \pi_{H, t}+\theta_{y} \Delta y_{t}$ \\
\hline Exchange Rate Target & $r_{n, t}=r_{n, t}^{*}+\theta_{s} s_{t}$ \\
\hline Managed Exchange Rate Level & $r_{n, t}=\rho r_{n, t-1}+\theta_{\pi} E_{t} \pi_{H, t}+\theta_{y} \Delta y_{t}+\theta_{s} s_{t}$ \\
\hline Managed Exchange Rate Change & $r_{n, t}=\rho r_{n, t-1}+\theta_{\pi} E_{t} \pi_{H, t}+\theta_{y} \Delta y_{t}+\theta_{s} \Delta s_{t}$ \\
\hline Optimal Monetary Commitment & $r_{n, t}$ responds to all state variables in the model \\
\hline \multicolumn{2}{|r|}{ Fiscal Policy Assignment } \\
\hline Generalized Fiscal Targeting Rule & $F S_{t}=F S+\alpha_{t a x}\left(T_{t}^{I}-T_{t}^{I} *+T_{t}^{I} \alpha_{t a x} T_{t}^{I *}\right)+\alpha_{C O P}\left(T C_{t}^{I}-T C_{t}^{I *}\right)$ \\
\hline Balanced Budget Target & $F S_{t}=F S$ \\
\hline Debt-to-GDP Target & $t_{t}^{I}=\alpha b_{G, t-1}$ \\
\hline $\begin{array}{l}\text { Structural Surplus Fiscal Target } \\
\text { (SSFT) }\end{array}$ & $t_{t}^{I}=-\left(1-\alpha_{t a x}\right) t_{t}^{N I}-\left(1-\alpha_{C O P}\right) t c_{t}+\left(\frac{1}{\beta(1+g)}-1\right) b_{G, t-1}+\frac{B_{G}}{P_{H} Y} r_{g, t-1}+g r_{t}$ \\
\hline $\begin{array}{l}\text { Structural Surplus Fiscal Target with } \\
\text { No Feedback on Government } \\
\text { Spending Shocks (SSFT*) }\end{array}$ & $t_{t}^{I}=-\left(1-\alpha_{t a x}\right) t_{t}^{N I}-\left(1-\alpha_{C O P}\right) t c_{t}+\left(\frac{1}{\beta(1+g)}-1\right) b_{G, t-1}+\frac{B_{G}}{P_{H} Y} r_{g, t-1}$ \\
\hline Optimal Fiscal Commitment & $r_{n, t}$ respon \\
\hline
\end{tabular}

Notation: $r_{n}$ is the short-term nominal interest rate; $y$ is output, $s$ is the nominal exchange rate, $\pi$ is CPI inflation, $\pi_{H}$ is PPI inflation, $P_{H}$ is the PPI, $F S$ is the structural fiscal surplus, $T^{I}$ are tax revenues from variable tax fiscal takings, $T^{N I}$ are tax revenues from flat-tax-rate-based fiscal takings, $T C^{I}$ are tax revenues from taxes on copper production, $g r$ is government spending, $b_{G}$ is the debt-to-GDP ratio. $\rho, \theta_{\pi}, \theta_{\pi}, \theta_{s}, \alpha, \alpha_{t a x}$ and $\alpha_{C O P}$ are policy parameters. $\Delta$ and $E$ are the difference and expectations operators, respectively. Starred variables indicate steady state values and small case express variables in deviation from their respective steady state.

\begin{tabular}{|c|c|c|c|}
\hline & Welfare Loss & $\begin{array}{c}\text { Consumption-Equivalent } \\
\text { Loss }(\%)\end{array}$ & $\begin{array}{c}\text { SS Annual Inflation } \\
\text { Target Required under } \\
\text { ZLB }^{2}\end{array}$ \\
\hline $\begin{array}{l}\text { Optimal Monetary-Fiscal } \\
\text { Commitment }\end{array}$ & 4.78 & 0 & 1.16 \\
\hline $\begin{array}{l}\text { Inflation Target on PPI plus } \\
\text { Balanced Budget }\end{array}$ & 30.46 & 2.45 & 8.6 \\
\hline $\begin{array}{l}\text { Inflation Target on PPI plus Debt- } \\
\text { to-GDP Ratio Target }\end{array}$ & 12.80 & 0.76 & 6.36 \\
\hline Inflation Target on PPI plus SSFT & 25.02 & 1.93 & 5.32 \\
\hline Inflation Target on PPI plus SSFT* & 8.20 & 0.33 & 3.24 \\
\hline
\end{tabular}

${ }^{1}$ Intertemporal expected welfare loss at time $t=0$ given by the sum of stochastic and deterministic welfare loss components.

${ }^{2}$ Given the unconditional variance for the nominal interest rate under the ZLB constraint, this is the steady state positive inflation rate that will ensure that the nominal interest rate stays at or above zero with a given (large) probability. 


\section{How Do Changes In Global Liquidity Affect Chile? ${ }^{1}$}

As financial globalization progresses, changes in global liquidity have become increasingly important determinants of expenditure and pricing patterns around the world. Staff analysis suggests that trends in global liquidity can positively affect financing conditions and growth in the four Latin American countries under study.

1. This chapter analyzes the impact of changes in global liquidity on Latin American countries with a special focus on Chile. The impact is quantified by estimating structural VAR models for four countries, namely Argentina, Brazil, Chile, and Mexico, using 19972007 data. For each country, the model includes a variable capturing global liquidity and a set of five domestic variables: output growth, the inflation rate, interest rate, equity returns, and the nominal effective exchange rate. ${ }^{2}$

2. Three liquidity measures are used to ensure that results are robust to the definition of global liquidity. The first measure is the world money stock (U.S. M0 money plus the sum of world international reserves), assuming that the world economy is fully integrated and can thus be portrayed as a closed economy. ${ }^{3}$ The second approach measures banks' funding liquidity using the G7 Ted spread (Libor minus T-bill rate). The third and final metric uses the VIX index to reflect the speculative motive of liquidity holding at a global level. ${ }^{4}$

3. By running impulse response functions for shocks to these liquidity measures, we are able to gauge the response of each country to changes in global liquidity. These shocks are derived by estimating univariate autoregressive residuals of the metrics described above. These residuals are found to be generally uncorrelated with each other-suggesting that they indeed reflect different concepts of liquidity.

\section{The findings tally with economic theory, with results similar across liquidity} measures but different across countries. As expected, positive global liquidity shocks tend to lower interest rates, increase equity return and output at home, and reduce the global interest rate or global risk premium - allowing countries to borrow more easily and on cheaper terms. More favorable financing conditions in each economy, in turn, stimulate economic activity. Given faster growth and lower interest rates, equity returns also increase.

\footnotetext{
${ }^{1}$ This chapter is a summary of a paper prepared by Akito Matsumoto (RES).

${ }^{2}$ We assume that the global liquidity conditions are exogenous to the country. In theory, this is in line with the assumption that each small open economy does not affect world variables.

${ }^{3}$ Using world international reserves is preferable to using the G7 money stocks, in part because the former capture recent important additions to global liquidity from the accumulation of saving in commodity exporting countries and East Asia.

${ }^{4}$ The liquidity measures are used separately to obtain three versions of each country model. All measures are transformed in such a way that positive values imply expansionary economic effects.
} 
5. Other key results from the analysis can be summarized as follows:

- $\quad$ Global liquidity contracted substantially during the recent international financial turmoil. As expected, the measure using Ted spreads was most affected as the sub prime crisis primarily hit the financial sector. Liquidity proxied by the VIX index also worsened significantly, reflecting a spike in risk premia. Likewise, global liquidity measures proxied by world international reserve growth also slowed - after years of rapid growth - but appears to have been

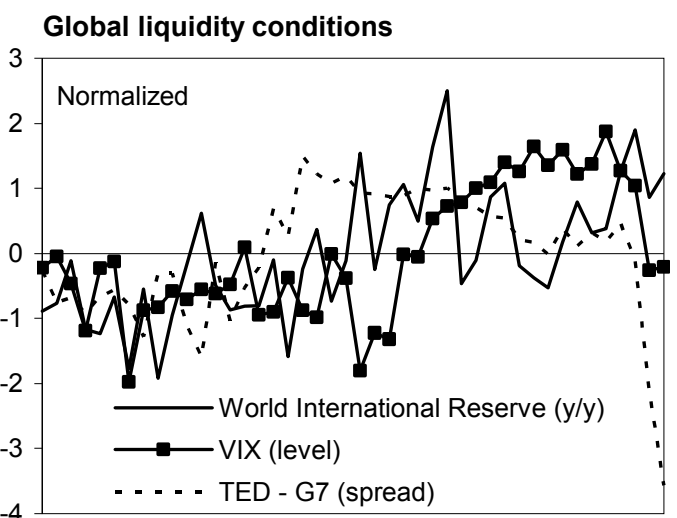

1997Q1 1998Q4 2000Q3 2002Q2 2004Q1 2005Q4 2007Q3 affected less than the other measures.

- $\quad$ Notwithstanding the similarities noted above, the magnitude of response and speed of convergence after a global liquidity shock differ across countries. Chile's output and inflation, for example, return quickly to equilibrium following the shock to global liquidity, and the economy is rather resilient to the shock. Mexico and Brazil have similar but somewhat more persistent responses. In contrast, the model for Argentina shows departures from equilibrium that are larger and more protracted.

- $\quad$ Impulse response functions to other shocks are also different across countries. In Chile, short-term interest rates increase immediately in response to shocks to either inflation or growth, and by a significant amount, indicating that monetary policy responds actively to inflationary pressures. In Mexico, interest rates respond to inflation in a similar way, but not as much to output. The response of Brazilian shortterm interest rates to inflation has been somewhat slower, although the reaction speed appears to have increased in the second half of the sample period. Model results for Argentina generally show a strong reaction of the exchange rate in addition to the interest rate response.

\section{These results support the notion that inflation targeting is a powerful stabilizing} force in the presence of global liquidity shocks. While the initial magnitude of the response to a change in global liquidity may reflect the degree of each country's dependence on external finance, the speed at which each country returns to equilibrium seems to depend primarily on the country's interest rate reaction - which in turn is highest for countries that have adopted an inflation targeting regime. 
Response to Global Liquidity Shocks
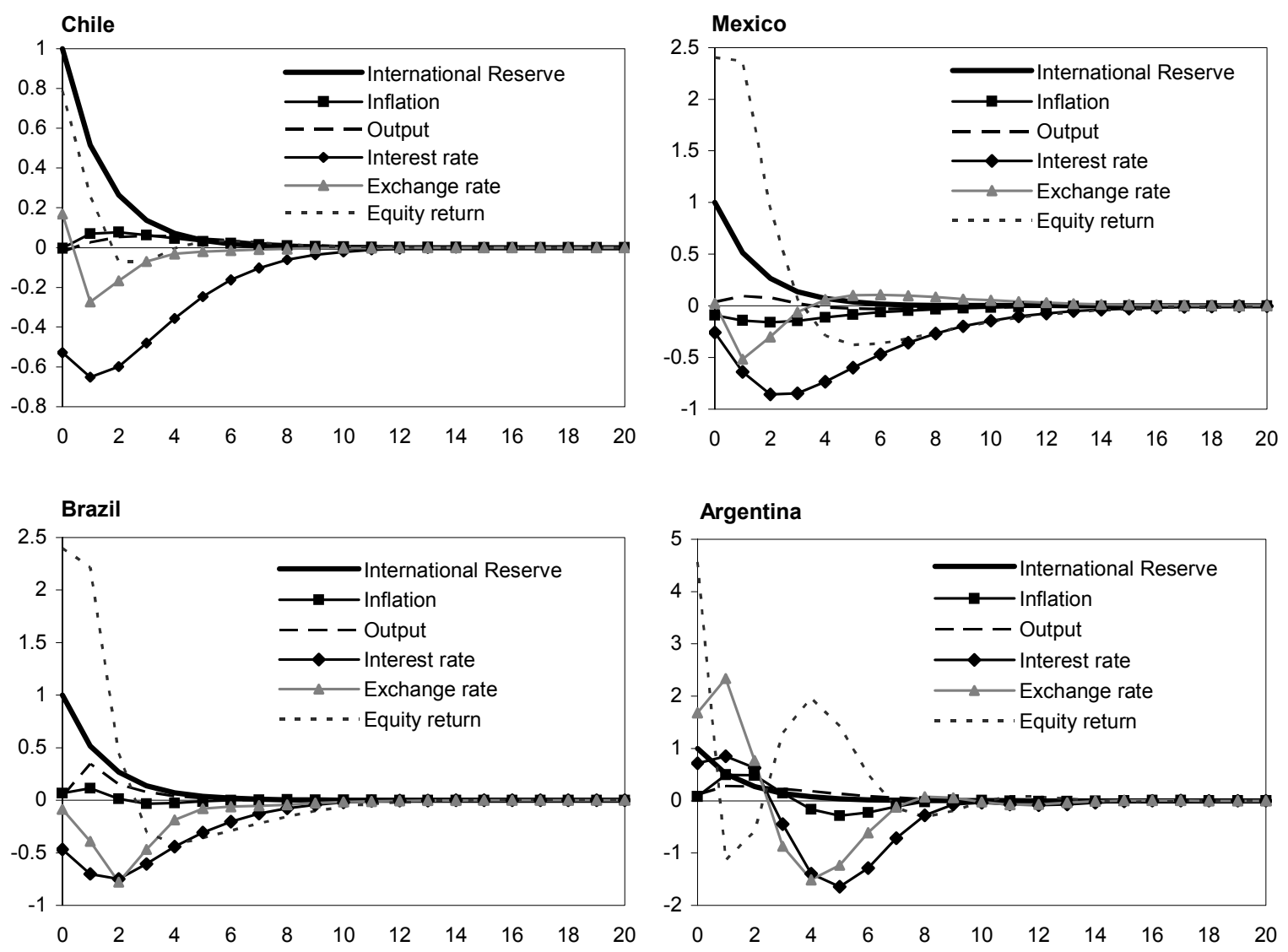

Response to Other Shocks (Chile Only)

Chile - Response to Output Shock

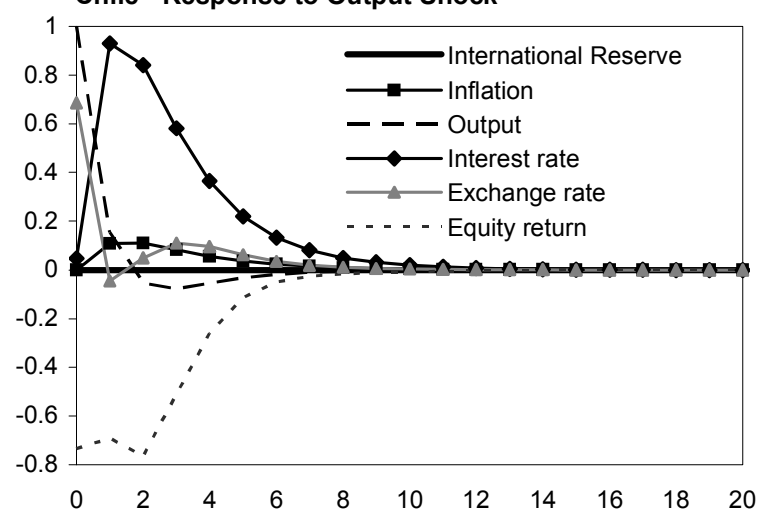

Chile - Response to Inflation Shock

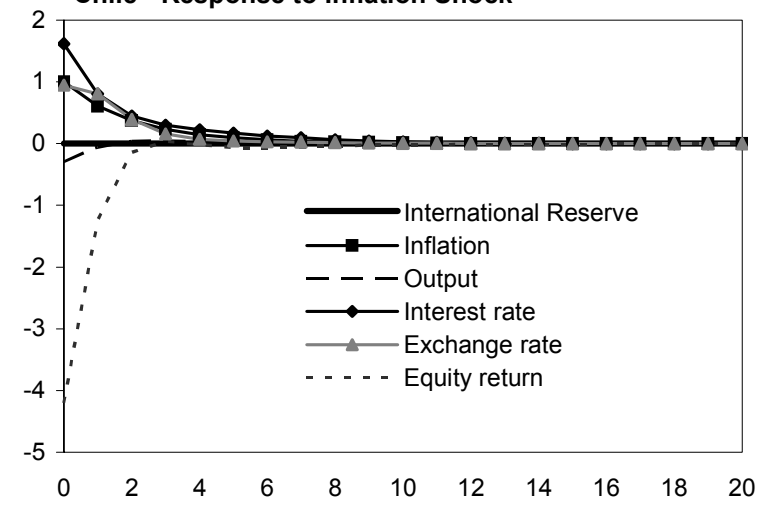




\section{Chile's Sovereign Wealth Funds: An International Perspective ${ }^{1}$}

Following the accumulation of large fiscal surpluses, Chile has established two sovereign wealth funds (SWFs) to partly finance future pension expenditure and maintain general government spending in case of an economic downturn. While maintaining a conservative investment policy, the government is developing a strategic asset allocation framework to increase the returns available to the annual budget, which in turn provides room for higher spending on priority needs.

\section{A. Domestic Background}

1. Chile's macroeconomic policy framework is anchored by the structural fiscal surplus rule. The rule sets a spending ceiling for each year consistent with a long-run surplus target of $1 / 2$ percent of GDP. Expenditure is based on structural, rather than actual revenues, taking into account estimates of potential GDP to calculate nonmining tax revenue, and longterm average prices for copper and molybdenum to estimate structural mining revenues.

2. The substantial accumulation of assets by the public sector is a natural outgrowth of that policy when mining revenues are high. In order to smooth government spending, the government saves surpluses in excess of the structural target in the Fund for Economic and Social Stabilization (FESS) to be used when revenues slow. It is thus to be expected that the government accumulates assets during periods of high copper prices, with income earned from those assets adding to structural revenue. These assets are available to finance government spending during a downturn, but given the significant increase in the size of the FESS, it is now being managed as a Sovereign Wealth Fund.

3. Indeed, tying FESS contributions to budget surpluses rather than mineral revenues sets the FESS apart from practices in other countries. In Norway, for example, all oil revenue is deposited into the country's Pension Fund, and withdrawals are set under an institutionalized framework. In Chile, the surplus rule imposes that not only copper revenue, but all revenues beyond the structural surplus target are saved in the FESS.

\section{The government has also created an SWF to finance part of the pension reform} that was passed by Congress this year. The new system guarantees a pension to all retirees, although the public pension benefit is reduced for those with larger self-financed pensions. While the inherently private character of the old system is retained, the new system does introduce a moderate long-term fiscal liability, which the government plans to address in part through the Pension Reserve Fund (PRF) and new mechanisms for measuring pension risks.

5. Chile's SWFs are thus an integral part of the macroeconomic framework. In 2006, the government strengthened the fiscal framework by establishing the PRF and FESS, and

\footnotetext{
${ }^{1}$ Prepared by James P. Walsh, Michael Papaioannou, Manmohan Singh (both MCM), and Eugen Tereanu.
} 
apportioning future fiscal surpluses between the two. ${ }^{2}$ The fiscal rule is designed to smooth government expenditure across the business cycle, providing for a counter-cyclical fiscal stance, and the government's decision to invest SWFs abroad supports this objective by reducing exchange rate volatility and avoiding Dutch disease.

\section{B. International Practices}

6. Recent shifts in the world economy have increased the number and size of SWFs. Some of the longer-established SWFs, e.g., those of Kuwait, Abu Dhabi, and Singapore, have existed for decades (Table 1). However, following the Asian financial crisis, many emerging market countries have increased stocks of international reserves, a trend strengthened by high commodity prices and global imbalances.

7. There are varying rationales for the establishment of SWFs. An often found rationale is to transform nonrenewable resources into sustainable and more stable future income. Saving commodity revenue can help avoid boom-bust cycles and spread the benefits of commodity wealth across generations. Indeed, most SWFs today reflect these motives. Oil-exporting countries own 23 of the 38 SWFs identified by the IMF, holding around 72 percent of all SWF assets. Two other motives for establishing SWFs are to balance the significant costs associated with excessive reserves accumulation (such funds are estimated to hold around 20 percent of SWF assets) and the need to secure future welfare obligations.

8. SWFs invest in a broad variety of assets, depending on individual objectives. For countries with reserves pools in excess of immediate central bank liquidity needs, creating a separate SWF can allow some monies to be managed with higher returns to compensate part of the cost of maintaining large liquidity stocks. Other SWFs are managed for income purposes, and may invest across all major asset classes, including alternative investments. The evidence suggests that, in general, SWFs act like long-term investors that have no desire to impact company decisions by actively using their voting rights.

9. Most SWFs employ external expertise. While public sector investment managers (such as reserve managers) have significant experience in fixed-income markets, they often have limited capacity for investment in other asset classes. SWFs thus often rely on external fund managers to implement investment decisions in areas where their own capacity is limited. This is true for funds that pursue aggressive investment strategies (such as private equity) as well as for those that pursue more passive equity-index strategies. Some large

\footnotetext{
${ }^{2}$ Under the 2006 Fiscal Responsibility Law, the first $1 / 2$ percent of GDP in budget surpluses accrues to the PRF. Remaining surpluses are banked in the FESS, although the government may choose to recapitalize the Central Bank with up to $1 / 2$ percent of GDP until 2011.
} 
Table 1. Market Estimates of Assets Under Management for SWFs

Based on Latest Available Information (As of February 2008)

(In billions of U.S. dollars)

\begin{tabular}{|c|c|c|c|}
\hline & \multirow[t]{2}{*}{ Name of Fund } & \multicolumn{2}{|c|}{ Assets (range) } \\
\hline & & Lower & Upper \\
\hline \multicolumn{4}{|c|}{ I. Oil and Gas Exporting Countries } \\
\hline UAE & Abu Dhabi Investment Authority & 250 & 875 \\
\hline Norway & Government Pension Fund-Global & 380 & 380 \\
\hline Saudi Arabia 1/ & No designated name & 289 & 289 \\
\hline Kuwait & $\begin{array}{l}\text { Reserve Fund for the Future Generations/ } \\
\text { Government Reserve Fund }\end{array}$ & 213 & 213 \\
\hline \multirow[t]{2}{*}{ Russia } & Reserve Fund & 125 & 125 \\
\hline & National Welfare Fund & 32 & 32 \\
\hline Libya & Libyan Investment Authority & 50 & 50 \\
\hline Qatar & State Reserve Fund/Stabilization fund & 30 & 50 \\
\hline Algeria & Reserve Fund/Revenue Regulation Fund & 43 & 43 \\
\hline USA (Alaska) & Alaska Permanent Reserve Fund & 40 & 40 \\
\hline Brunei & Brunei Investment Authority & 30 & 30 \\
\hline Kazakhstan & National Fund & 21 & 21 \\
\hline Malaysia & Khazanah Nasional BHD & 19 & 19 \\
\hline Canada & Alberta Heritage Savings Trust Fund & 16 & 16 \\
\hline Nigeria & Excess Crude Account & 11 & 11 \\
\hline Iran & Foreign Exchange Reserve Fund & 9 & 9 \\
\hline Azerbaijan & State Oil Fund & 2.5 & 2.5 \\
\hline Oman & State General Reserve Fund & 2 & 2 \\
\hline Timor-Leste & Petroleum Fund of Timor-Leste & 1.4 & 1.4 \\
\hline Venezuela & FIEM & 0.8 & 0.8 \\
\hline Trinidad \& Tobago & Revenue Stabilization Fund & 0.5 & 0.5 \\
\hline \multicolumn{4}{|l|}{ II. Asian Exporters } \\
\hline Singapore & Government Investment Corp. & 100 & 330 \\
\hline China & State Foreign Exchange Investment Co. & 200 & 200 \\
\hline Singapore & Temasek & 108 & 108 \\
\hline Hong Kong & Investment Portfolio (HKMA) & 100 & 100 \\
\hline Korea & Korea Investment Corp. & 30 & 30 \\
\hline Taiwan, Province of China & National Stabilisation Fund & 15 & 15 \\
\hline \multicolumn{4}{|l|}{ III. Other Countries } \\
\hline Australia & Australian Future Fund & 54 & 54 \\
\hline Chile & FEES and Pension Reserve Fund & 19 & 19 \\
\hline Botswana 1/ & Pula Fund & 4.7 & 4.7 \\
\hline Kiribati & Revenue Equalization Fund & 0.4 & 0.4 \\
\hline Total & & 2,191 & 3,066 \\
\hline
\end{tabular}

Sources: Deutsche Bank; Morgan Stanley; news articles; Peterson IIE; PIMCO; and SWF websites.

1/ Part of the investment tranches of these countries' central banks. 
SWFs (e.g., Norway, Abu Dhabi, and Singapore) have highly professional in-house investment managers, and are thus able to rely less on external managers. ${ }^{3}$

\section{Rules and Institutionality: How does Chile compare?}

\section{Asset Allocation}

10. Chile's SWFs have been invested relatively conservatively. The PRF and the FESS at present are both invested in cash and sovereign securities (Table 2). Most other SWFs invest heavily in equities and riskier fixed-income securities, and quite a few invest in private equity, or take large shares in companies, both of which have been excluded as investment categories by the Chilean authorities.

\section{Both the PRF and the FESS are moving toward a strategic asset allocation (SAA)}

framework. Higher returns are the primary objective of moving from a very conservative and liquid portfolio of sovereign bonds and cash to a slightly more return-oriented portfolio. The authorities have proposed a new allocation for end-2008 which would invest both funds in a wider variety of securities, and are developing a framework for the optimization of the longterm SAA for both funds taking into account Chile's overall macroeconomic position.

\begin{tabular}{|lcc|}
\hline \multicolumn{2}{|c|}{ Table 2. Asset Allocation of Chile's Sovereign Wealth Funds } \\
\\
\multicolumn{2}{|c|}{ (in percent of total assets) } \\
\hline & Current & End-2008 Target \\
Sovereign Bonds (Nominal) & 66.5 & 45 \\
Sovereign Bonds (Inflation-Indexed) & 3.5 & 15 \\
Money Market Assets & 30 & 5 \\
Corporate Bonds & & 20 \\
Equities & 100 & 15 \\
Total & & 100 \\
\hline
\end{tabular}

\section{Nevertheless, the FESS will remain more conservative than other stabilization}

funds. Similar to oil-rich nations such as Saudi Arabia and the U.A.E., Chile's stabilization fund is small relative to its unextracted natural resources. This argues for an SAA focused mostly on maximizing asset returns within an acceptable level of risk. However, Chile's policy of investing only in publicly traded securities will continue to separate it from larger funds such as those of Abu Dhabi and Singapore, which also engage in private-equity transactions.

\footnotetext{
${ }^{3}$ The IMF and Chile are part of a broad effort to draft a set of voluntary generally accepted principles and practices (GAPP) for SWFs. Issues to be addressed include legal practices, coordination with macroeconomic policies, institutional framework, governance structure, transparency and accountability, and risk management.
} 
13. The PRF's objective relates to future pension liabilities. PRF resources are intended to be used on specific pension liabilities, which argues for managing the assets such that the government has access to the required liquidity when the liabilities come due. Most other national pension funds are invested in long-term domestic securities. Given Chile's decision to invest PRF funds abroad, one option would be for the fund to invest in fixed-income securities denominated in currencies that co-move with the peso, such as those of other natural resource exporters.

\section{Management of Chile's SWFs}

14. While both SWFs are public assets, they are operationally managed by the Central Bank. The Banco Central de Chile (BCC) has signed an agreement with the Ministry of Finance to manage both funds as a fiscal agent. The Ministry of Finance has sent investment instructions to the BCC, which implements the investments. Decisions about disbursements from the funds are made by the Ministry of Finance, but decisions about investment choices within the government's investment instructions are being made by the BCC.

15. Chile's SWFs are being managed transparently, and the government is committed to best practices in this area. The authorities publish monthly reports on the size and portfolio composition of both funds, and more extensive quarterly reports discussing performance relative to financial market developments and established benchmarks.

Moreover, both the authorities and its Financial Advisory Committee (FAC) are committed to public discussion of the funds' strategies, and all asset income and use of PRF and FESS assets are included in the annual budget. ${ }^{4}$ As stated above, Chile is also committed to the development and implementation of GAPP.

\section{Outlook}

\section{Pension Reserve Fund}

16. The PRF can be used to directly finance pension expenditure beginning in 2016. To protect the PRF's principal, however, disbursements from the PRF will be capped at one third of the increase in pension spending after 2015. Assuming future pension costs evolve according to the authorities' baseline forecast, staff estimates that the PRF will eventually be able to cover one quarter of the additional expenditure incurred by the new pension system.

17. According to staff calculations, the PRF will remain well-capitalized in the medium term. Staff estimates that the ceiling on PRF outflows will remain below 0.15 percent of GDP for the next twenty years. These amounts would be greatly exceeded by the annual

\footnotetext{
${ }^{4}$ An additional example of transparency has been the recent release of the FAC's Annual Report that discusses the rationale for changing the investment policy of the funds (see http://www.hacienda.cl/fondos).
} 
surplus transfers, leading to continued accumulation during this period, from about $1 \frac{1}{4}$ percent of GDP at end-2008 to around 51/2 percent of GDP in 2020.

\section{Fund for Economic and Social Stabilization}

18. With macroeconomic stabilization its primary objective, the FESS should be in a position to finance government expenditure even under a sharp decline in revenues. An optimal asset allocation for the FESS will have to take into account the uncertainty regarding future economic and financial developments. However, with the FESS approaching 13 percent of GDP by end-2008, the fund provides a comfortable insurance level for Chile's medium-term liquidity needs.

\section{Staff analysis confirms that the authorities have room to invest the FESS into} assets with longer duration. Simulations on the basis of a VAR model allowing for global shocks confirms that a significant portion of the FESS is unlikely to be drawn down over the next 15-20 years, and can therefore be invested in assets with longer duration. This finding is also consistent with the government's decision to set aside US $\$ 6$ billion ( $33 / 4$ percent of GDP) in a Bicentennial Fund, and to change the investment policy towards new asset classes and a much longer duration. All revenues related to the Bicentennial Fund would count as structural revenue, and are to be used to provide for scholarships of Chilean students abroad.

\section{In the long run, however, the FESS would be expected to stabilize relative to GDP.}

The structural fiscal surplus target of $1 / 2$ percent of GDP corresponds to a steady-state level of both SWFs (that is, the sum of FESS and PRF) of around 6 percent of GDP. ${ }^{5}$ Therefore, while Chile's SWFs are likely to continue to grow in the medium-term as long as copper prices remain high, the structural surplus rule sets an implicit limit on their long-term size.

\footnotetext{
${ }^{5}$ The long-term asset stock of the FESS $(f)$ is $f=b / \gamma$, where $b$ is the fiscal surplus target ( $1 / 2$ percent of GDP) and $\gamma$ the assumed trend nominal GDP growth rate ( 8 percent).
} 


\section{DeEPENING ChILE's CAPITAL Markets Through GLOBAL INTEgRation ${ }^{1}$}

In many respects, Chilean financial markets are among the most developed in Latin America. However, key challenges remain, notably deepening the secondary market and increasing the global integration of Chilean capital markets. Removing obstacles for foreign investors and strengthening the financial sector infrastructure, as well as improving the framework for public debt management, would go a long way achieving these objectives.

1. Chile's financial markets are generally well-developed, and the corporate bond market is large by emerging market standards. However, some characteristics of the fixed income market suggest that liquidity is not very high:

- The outstanding stock of domestic public debt securities is low in global comparison both in relative and absolute terms (Figure 1 and 2).

- $\quad$ Turnover in the secondary public debt market is comparable to that of emerging countries with moderately liquid bond markets, but liquidity is scarce in the corporate bond market (Figure 3).

- $\quad$ Foreign investor participation is minimal compared to local bond markets in other emerging markets.

2. As fiscal surpluses in recent years have reduced gross public debt, deepening the domestic secondary market for public debt is becoming a challenge. The large share of buyand-hold investors contributes to the problem of low liquidity, with pension funds assets at six times of government bonds and two times of total domestic bonds (Figure 4). However, pension funds' high demand for domestic bonds may abate somewhat in the future with the ongoing liberalization of foreign investment limits.

\section{Likewise, Chile's derivatives markets show strength in some areas, but need to be} developed further in others. Total over-the-counter foreign exchange (FX) market turnover is in line with the country's income level, but this masks significant differences across market segments. ${ }^{2}$ While Chile's FX forward turnover is high relative to both GDP and GDP per capita, the country ranks very low in terms of FX swap turnover, and very little FX options are traded (Figures 5 and 6). Turnover in cross-currency swaps and interest rate derivatives is also low (Figures 7 and 8). Moreover, trading with foreign counterparties has not reached the relatively high levels shown in many other emerging market countries (Table 1).

\footnotetext{
${ }^{1}$ This chapter is a summary of a technical paper prepared by Zsófia Árvai (MCM).

2 The peer group chosen for this analysis is investment-grade emerging market countries and Australia, Canada and New Zealand. The analysis is based on data from the 2007 BIS Triennial Central Bank Survey.
} 
Table 1. Chile: OTC FX Trading Activity with Foreign Dealers

(In percent of trading activity)

\begin{tabular}{lrr}
\hline & 2001 & 2007 \\
\hline Developed Countries & 60.2 & 56.6 \\
Emerging Markets & 24.7 & 42.4 \\
& & \\
EM Countries with lowest shares & & \\
China & - & 0.0 \\
Colombia & 6.9 & 6.8 \\
Philippines & 11.1 & 14.5 \\
Brazil & 4.5 & 19.5 \\
Chile & - & 22.8 \\
Peru & 22.8 & 25.0 \\
& & \\
\hline
\end{tabular}

Source: IMF staff estimates based on BIS (2007).

4. Larger participation by foreign investors could bring important benefits to Chile. Foreign participants could help diversify an investor base dominated by large domestic institutional investors that often have very similar portfolio allocation strategies, increasing market heterogeneity and reducing the potential for one-sided bets. They would potentially add demand for Chilean assets as pension funds can increasingly invest abroad, and would likely contribute to the development of the nominal bond market (domestic investors have a preference for inflation-protected securities). Ongoing improvements in the regulatory and supervisory framework (including the shift to Basel II capital standards) will help manage the risks associated with a larger presence of foreign investors.

\section{Attracting foreign investors on a larger scale would seem to require action on a}

number of fronts. In addition to impediments for onshore derivative trading, low public debt, and remaining shortcomings in market infrastructure, the development of Chile's fixed income and derivatives markets would require addressing the following key issues:

- $\quad$ Chile levies a 35 percent capital gains tax on debt instruments for most foreign investors. There is a cumbersome administrative process to exempt foreign institutional investors.

- $\quad$ The central bank law restricts the use of the local currency in settling most capital account transactions with non-residents, segmenting the offshore and onshore derivative markets.

- $\quad$ There is a lack of regulation for the netting of transactions in the derivatives market.

- $\quad$ Pension funds and insurance companies face strict restrictions on the use of derivatives. 
- $\quad$ Public debt issuance is relatively fragmented between the central bank and the government, between inflation-indexed and nominal bonds, and across maturities.

- $\quad$ Sovereign benchmark issues have grown in size, but typically remain at US\$400-500 million, a fraction of benchmarks in mature and liquid emerging bond markets.

6. Reforms are also needed to facilitate local currency issues by foreigners, one of the authorities' reform objectives. Attracting foreigners to issue local currency-denominated bonds in Chile could help expand the supply of investment assets and increase portfolio diversification for domestic investors. Chile could benefit by following the example of countries like Canada and Australia that have successfully developed local-currency denominated markets for non-residents. However, the success of these countries depended on important preconditions, not all of which are currently present in Chile. Key impediments to local currency issues by foreigners include:

- Only investors of a limited group of countries are permitted to issue debt in Chile.

- The securities issuance process is relatively slow, especially for first-time issuers.

- $\quad$ The stamp tax raises the cost of local bond issuance.

- $\quad$ The cross currency swap market is relatively small, limiting the extent to which foreign issuers can manage their exchange rate exposures.

- $\quad$ Credit risk management capacities by some institutional investors may need to be upgraded to manage exposures to non-sovereign foreign entities. 
Fig.1: Size of Domestic Bond Markets 1/

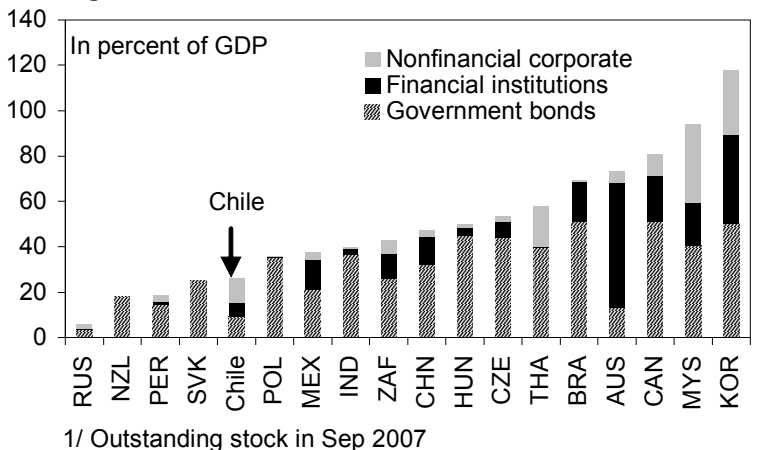

Fig. 3: Annual Trading of Locally Issued Bonds 1/

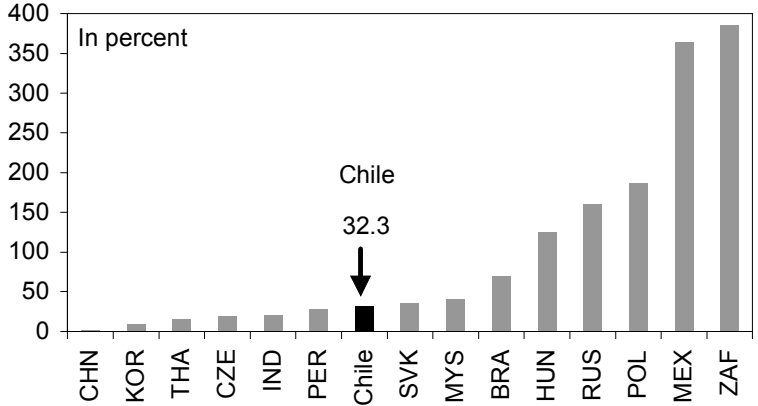

1/ As share of outstanding local bonds in Sep 2007

Fig. 5: OTC FX forwards $1 /$

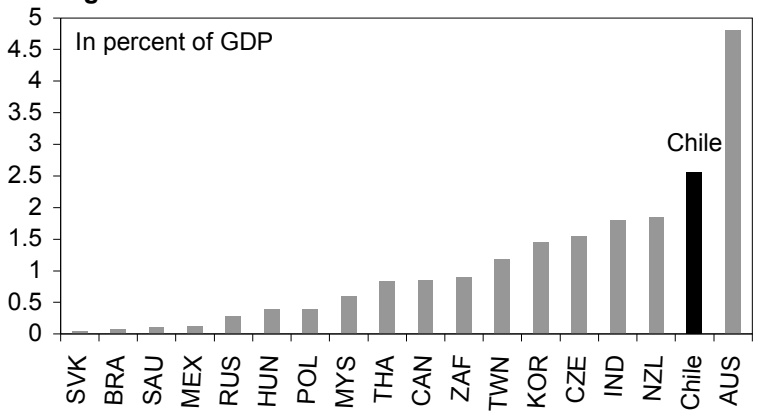

1/ Annualized turnover, 2007

Fig. 7: ОTC Cross Currency swaps $1 /$

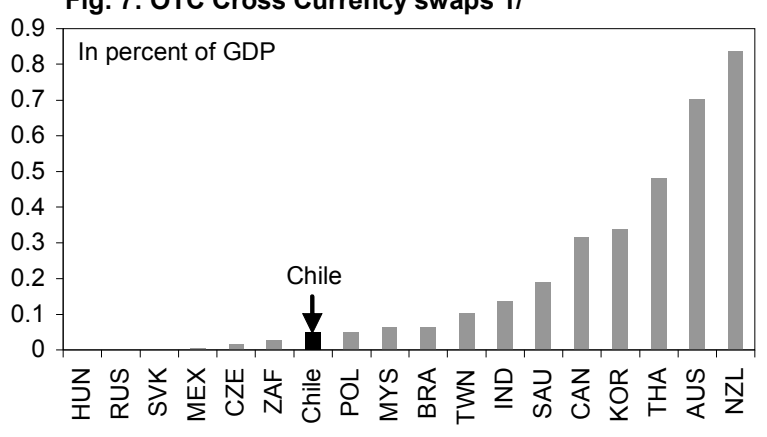

1/ Annualized turnover, 2007
Fig. 2: Absolute Size of Domestic Bond Markets 1/

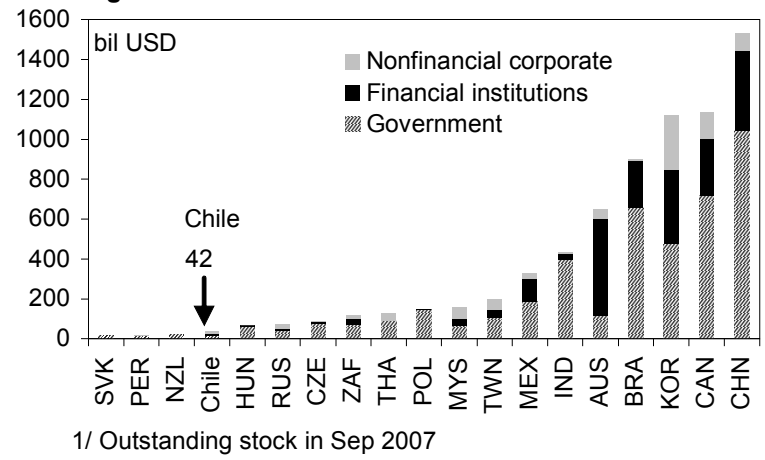

Fig.4: Pension Fund Assets 1/

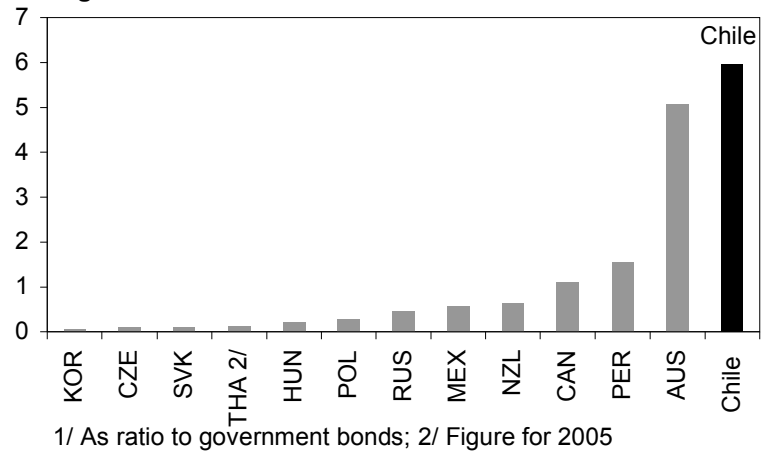

Fig. 6: OTC FX swaps 1/

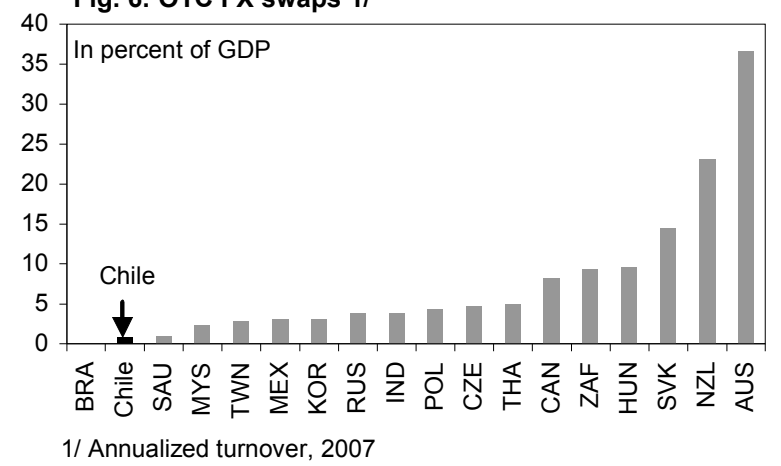

Fig. 8: Total IR derivatives 1/

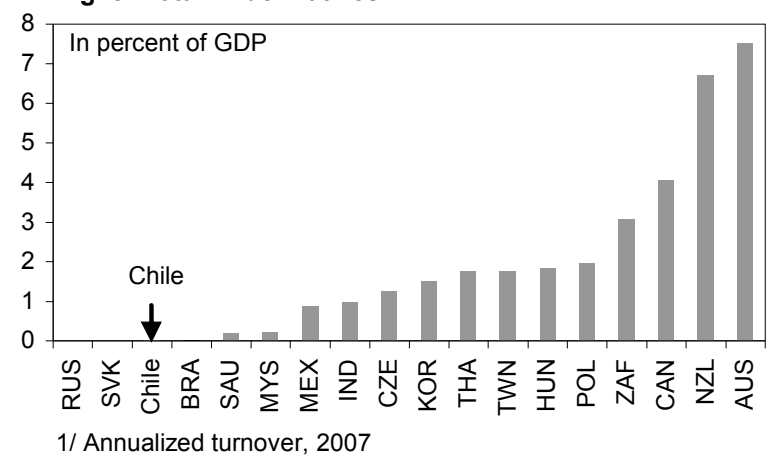

Source: EMTA,OECD, BIS and BIS Triennial Central Bank Survey 2007 